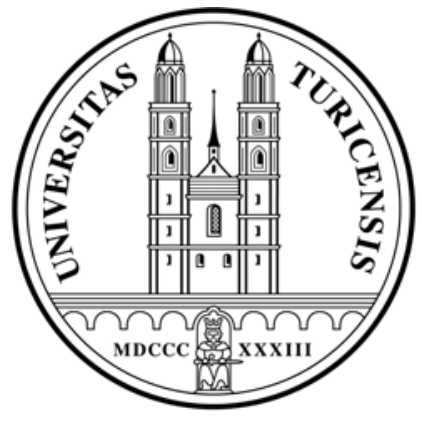

Institute for Empirical Research in Economics

University of Zurich

Working Paper Series

ISSN 1424-0459

Working Paper No. 493

Competition and Innovation: Does the Distance to the Technology Frontier Matter?

Simon Alder

July 2010 


\title{
Competition and Innovation: Does the Distance to the Technology Frontier Matter?*
}

\author{
Simon Alder ${ }^{\dagger}$
}

June 2010

\begin{abstract}
This paper provides new evidence on the relationship between innovation, competition and distance to the technology frontier, using enterprise surveys from 40 developing and transition countries. Different from previous empirical studies, the distance to frontier is measured by a firm's technology level relative to its main competitor. This self-reported comparison allows to capture a crucial determinant of a firm's business strategy and its response to competition. The findings from the empirical analysis are as follows. Firstly, firms with more advanced technology compared to their main competitors have more product innovations. Secondly, there is evidence that innovation and competition are more positively correlated at low levels of competition than at high levels. With some measures of competition, the correlation is highest at intermediate levels of competition, which suggests an inverted-U relationship. Thirdly, in certain specifications, competition is most positively correlated with product innovation when a firm is more advanced than its main competitor. In other cases, this correlation is strongest for firms that are at the same technology level as their competitors. However, the differences in the correlations between more and less advanced firms are not always significant.
\end{abstract}

JEL: O16, O31, O33, O38, O40, L16

Keywords: Market Structure, Competition, Innovation, Technology Adaption, Growth

*I wish to thank Bernhard Ganglmair, Stephan Kyburz, Patrick Ley, Andreas Müller, Sigrid Röhrs, Yikai Wang, Christoph Winter, Fabrizio Zilibotti and seminar participants at the University of Zurich and Barcelona Graduate School of Economics. Financial support from the European Research Council (ERC Advanced Grant IPCDP-229883) is gratefully acknowledged.

${ }^{\dagger}$ University of Zurich, Institute for Empirical Research in Economics, Mühlebachstrasse 86, CH-8008 Zurich, Switzerland, email: salder@iew.uzh.ch. 


\section{Introduction}

Private enterprises account for a substantial fraction of investment in innovation, which is widely recognized as a major driver of economic growth. These firms base their investment decisions on the opportunities and constraints given by their business environment. Policies that aim to foster growth and development through changes in the business environment are therefore particularly promising when they are based on a good understanding of how firm's innovative activities are related to their business environment. This paper contributes to this by using firm-level data to investigate particular aspects of firm characteristics and their business environment. More precisely, I am interested in how industry competition is related to a firm's innovative output and how this relationship depends on a firm's technological development. To do so, I focus on three hypothesis that emerge from the existing theory and empirical evidence: 1) firms that are technologically more advanced than their competitors innovate more, 2) innovation is increasing in competition at low levels of competition and decreasing at high levels, and 3) competition is more positively correlated with innovation when firms have more advanced technology.

I test these three predictions using standardized surveys of 9'000 firms from 40 developing and transition countries. The data set includes new measures of technology and competition that provide additional insight into the relationship between innovation, competition and technology. In the existing literature, the relative level of technology is usually captured as the productivity of a particular country, industry or firm compared to the highest productivity. Instead of productivity, this paper uses a measure for how firms perceive their technology to be in comparison to their main competitor. The advantage of this measure is that it captures a particularly relevant frontier in the sense that the technology of the main competitor constitutes a crucial factor for a firm's business strategy and performance. Empirical evidence shows that there is significant productivity dispersion across industries and countries and also between firms within the same industry and country. Furthermore, the evidence suggests that the different frontiers that emerge from such comparisons of productivities, for example the national and the global technology frontiers, are not equally important for firms at different productivity levels. It is therefore interesting to look at the technology of direct competitors as another relevant frontier and this is one of the main contributions of this paper. Competition is often measured with concentration indices or average price-cost margins. In this paper, competition is captured by industry averages of market power that is derived 
from a hypothetical monopolist test. These two measures of technology and competition are then related to an index for product innovation in order to test the three predictions above.

The results are as follows. Firms with more advanced technology compared to their main competitors have more product innovations. Secondly, there is evidence that an increase in competition is associated with a larger increase in innovation if the initial level of competition is low. For some measures of competition, the correlation with innovation is highest at intermediate levels of competition, suggesting an inverted- $U$ relationship between competition and innovation. Thirdly, the interaction between competition and advanced technology is positive in the majority of the specifications, but the significance levels are generally low and change with the measure of competition. For continuous measures, firms which perceive themselves to be at a similar technology level as their main competitor are most positively affected by competition. The results are different when competition is captured by the distribution of firms across different categories of market power. More advanced firms then seem to be affected by different categories than firms that are at the same technology level as their main competitor. However, there is no robust pattern across different measures of competition and the difference to the less advanced firms is not always statistically significant. When the sample is restricted to lower-middle income countries, then the interaction terms are highly significant and the results are mostly consistent with the three hypotheses.

The rest of the paper is structured as follows. Section 2 discusses the literature and the main predictions. Section 3 presents the data that is used for the empirical analysis and provides some descriptive statistics. The results and an extension are discussed in Sections 4 and 5. Section 6 concludes.

\section{Theoretical framework and related literature}

The main arguments of this paper are based on two endogenous growth models in which innovation is undertaken by incumbent intermediate good producers. In Acemoglu, Aghion and Zilibotti (2006), entrepreneurs can choose between innovation and imitation. Since it is possible to imitate from the technology frontier, less advanced firms rely more on imitation and firms close to the frontier more on their own innovations. Furthermore, innovation requires more skills and a selection of good entrepreneurs. These two requirements are fostered by intense competition, which consequently is more beneficial for advanced firms that rely on innovation. Using cross-country data on productivity 
and on research and development (R\&D) intensity, they find a positive correlation between the proximity to the productivity frontier and R\&D. Furthermore, they provide evidence that countries with weak competition (measured by high entry barriers) experience a stronger slowdown in growth rates when they approach the frontier than countries with more competition. Consequently, having weak competition is more harmful when a country is closer to the frontier, which is consistent with the prediction of the model. A similar result is reached by Aghion et al. (2006), who interact firm entry with distance to the productivity frontier. They find evidence that the effect of entry on productivity growth is more positive closer to the frontier. A number of other studies provide additional empirical evidence regarding distance to frontier and innovation. Bartelsman, Haskel and Martin (2008) investigate how firms at different technology levels are affected by the national and the global technology frontier. They find that the national frontier generally has a stronger impact on a firm's productivity growth than the global frontier. Furthermore, those firms that lag behind the most are often unable to imitate from the global frontier. The effect of the global frontier, thus, is decreasing in a firm's distance to this frontier. But they also show that the national frontier has a strong effect on firms even when they are far behind. This implies that there are differences between the effects of various technology frontiers and that these differences depend on a firm's distance to these frontiers. A different approach is taken by Coad (2008), who focuses on the value of firms and how it depends on $R \& D$ efforts and the distance to the frontier. He finds that R\&D is more beneficial for a firm's value when it is initially closer to the frontier, indicating that innovation is a more important business strategy closer to the frontier.

The second model on which this paper builds is discussed in Aghion et al. (2005). They assume that incumbent firms can innovate step-by-step and that they only face competition if other firms are at the same technology level or ahead. Firms have the possibility to escape their competitors by innovating if they previously were at the same level, or catch up if they were one step behind. The key insight is that an increase in competition has a positive effect on innovation when firms are at the same technology level. Competitive pressure from the other firms then provides incentives to innovate in order to move ahead of the competitors and thereby escape competition. Firms are likely to be at the same technology level if competition is weak and the model therefore predicts that a marginal increase in competition has a positive effect if the initial level of competition is low. When competition is already strong, then firms that lag behind have no incentives to catch up, because they anticipate the low rents from competition with 
the other firms if they were to innovate. There are, therefore, more firms at different technology levels and a further increase in competition has a negative effect because it discourages innovation by laggards. This leads to an inverted-U relationship between competition and innovation. Aghion et al. (2005) provide empirical evidence for such an inverted-U relationship using a panel of UK firms. There are also a number of other empirical studies that focus on the link between competition, innovation, and growth and they mostly find a positive effect of competition. To a large extent, these studies have been in a contradiction with the earlier models of endogenous growth, which predicted a negative link between competition and innovation, because high competition reduced the rents from innovating in those models. ${ }^{1}$ For example, Nickell (1996) observes that firms with higher market shares have lower levels of productivity. Furthermore, having higher rents is associated with lower productivity growth, which suggests that market power has a negative effect on performance. Blundell, Griffith and Van Reenen (1999) find that concentration at the industry level is negatively associated with firm innovation. But when they include the market share of the individual firm and estimate the effect on firm innovation, then they find that this effect is positive. Consequently, industry competition is positively associated with innovation, but those firms that have the highest market shares innovate the most. A comparable conclusion is reached by Carlin, Schaffer, and Seabright (2004), who use a similar enterprise survey as is used in this study. They find that market power of an individual firm is positively associated with its innovative output, but that the number of competitors is also positively related to innovation, suggesting that competitive pressure also has a positive influence.

Overall, recent theory and empirical evidence suggests that 1) firms closer to the technology frontier innovate more, 2) innovation is positively correlated with competition at low levels of competition and negatively at high levels, i.e. there is an inverted-U relationship between competition and innovation, and 3) competition has a more positive effect on firms closer to the frontier or at similar technology levels as their competitors. Furthermore, the evidence also shows that there are substantial differences not only between firms' technology levels, but also with respect to how they are affected by different frontiers. This has two implications for further empirical analysis. Firstly, given the heterogeneity across firms, it seems useful to look at the relationship between technology, innovation, and competition at the micro level. Secondly, the unequal effects of national and global technology frontiers on firm performance indicate that it is important to consider different frontier. The contribution of this paper is that it uses

\footnotetext{
${ }^{1}$ See Aghion and Griffith (2005) for an overview.
} 
a new firm-level measure of distance to the technology frontier. As will be discussed in the next section, the variable used here captures a firm's technology relative to its main competitor and provides a natural way to investigate the relationships between competition, innovation, and technology in the existing theoretical framework.

\section{Data}

The three key variables for this study are innovation, competition and the technology of a firm compared to its main competitor. The data is obtained from a large cross-country enterprise survey conducted by the World Bank between 2002 and 2008. About 9'000 firms in the data base from 40 developing and transition countries report all variables of interest for this study.

To measure the relative technology level, firms were asked whether their technology is more advanced than the one of their main competitor, about the same, or less advanced. The important feature of this variable is the comparison with another firm that is perceived to be the main competitor. This may be a domestic or a foreign firm and can have various levels of technology itself. It therefore does not represent the global technology frontier in terms of productivity, but rather the frontier on the relevant market for the firm. Since we are interested in the link between competition, innovation, and technology, this is a particularly informative measure and closely corresponds to the model in Aghion et al. (2005). It is also reasonable to expect the competitors to be a relevant technology frontier in the sense that they determine imitation possibilities and business strategies. The measure thus captures the technology frontier also in a broader way and is applicable to the model in Acemoglu, Aghion and Zilibotti (2006).

Market power is captured by a simplified hypothetical monopolist test. This test asks how customers would react if a firm increased its price by, for example, 10\%. The test therefore captures the price elasticity and is also referred to as SSNIP (Small Significant Non-transitory Increase in Price). This test is simplified here by letting respondents choose between four categories: (1) Our customers would continue to buy from us in the same quantities as now, (2) Our customers would continue to buy from us, but at slightly lower quantities, (3) Our customers would continue to buy from us, but at much lower quantities, and (4) Our customers would stop buying from us. To derive a measure for industry competition from firm-level market power, I follow the approach by Aghion et al. (2005), who calculate the average Lerner Index of UK firms in the same industry $s$ as $\overline{l_{s}}=\frac{1}{N_{s}} \sum_{i \in s} l_{i}$, where $l_{i}$ is the Lerner Index of firm $i$ and $N_{s}$ is the number of firms 
in industry $s$. The main differences in my calculation are that the Enterprise Surveys only distinguish four different levels of market power and that a cross-section of firms in different countries is used instead of a panel of UK firms. Calculating averages is only possible here if the intervals between the levels are assumed to be the same such that market power is roughly measured on a cardinal scale. If this is the case, then one can write competition as $\bar{m}(i)_{c, s}=\frac{1}{N_{c, s}} \sum_{i \in c, s} m(i)$, where $m(i) \in\{1,2,3,4\}$ is the inverse market power from the answers to the SSNIP test and $N_{c, s}$ is the number of firms in country $c$ and industry $s$ in which firm $i$ is located. To derive this average, all 28'000 firms from the data set that report their market power are used. This larger sample includes firms from 26 industries and 60 countries. After dropping industrycountry combinations with less than three firms, 1143 combinations are left, each with an according average market power that can be used as a measure for the intensity of competition in this industry. ${ }^{2}$

Firms were also asked whether they have developed a new product, upgraded an existing product, or introduced a new technology. The empirical analysis will focus on product innovation and upgrading in order to abstract from technology innovation, because technology innovations would have led to higher current technology levels and this would lead to a problem of simultaneity between innovation and technology. The innovation index constructed from the two binary variables for product innovation and upgrading takes the maximum value of two if both measures were undertaken, one if only one of the two was undertaken, and zero if none of them was undertaken. The index is constructed in such a way that an increase by one unit corresponds roughly to one additional initiative. ${ }^{3}$

\section{Figure 1: Quadratic fit of firm level product innovation}

To illustrate the link between competition and innovation graphically, Figure ?? plots the quadratic fit of product innovation of a firm against competition (average inverse market power) in the country and industry of this firm. As can be seen in the bottom right-hand side graph, low levels of competition are associated with low values of product innovation. As industry competition increases, product innovation first rises, but then falls after a certain level of competition is reached. This is in line with the inverted-U relationship predicted by the theory. When looking at the graphs for each technology

\footnotetext{
${ }^{2}$ One problem here is that the industry or the country may not be the relevant market for a firm, since some firms operate on a smaller market, while others face competition from abroad.

${ }^{3}$ See Carlin, Schaffer, and Seabright (2004) for a similar index.
} 
level separately, then we see that more advanced firms generally have higher innovation and this is consistent with the assumption that firms closer to the frontier innovate more. Firms which are at the same technology level as their competitors have a steeper curve and a peak at a higher level of competition. This is also what the theory predicts, because firms at similar levels have strong incentives to escape competition. The graphs provide some descriptive evidence and suggest that all three predictions from the theory are reflected in the data.

\section{Empirical strategy and results}

The empirical analysis of this paper investigates the relationship between innovation of individual firms, their technology, and the competitive environment. Enterprise survey data from 40 developing and transition countries is used to assess whether the correlations between the three key variables follow the pattern that are predicted by the theory. The three hypotheses are that 1 ) technologically more advanced firms innovate more than firms which are less advanced, 2) innovation is increasing in competition at low levels of competition and decreasing at higher levels, i.e. there is an inverted$\mathrm{U}$ relationship between competition and innovation, 3) technological leaders are more positively affected (in terms of innovation) by competition than laggard firms.

For the choice of the relevant firm characteristics, I mostly follow Carlin, Schaffer, and Seabright (2004), and Almeida and Fernandes (2008), who use similar data sets to analyze innovation. The explained variable is the innovation index and the set of explanatory variables includes the relative technology level, competition, size, age, private and state ownership, exports and imports, and education of the workforce. ${ }^{4}$ These variables will be used to test Hypothesis 1 and 2. The third hypothesis implies that the correlation between innovation and competition depends on the level of technology. Therefore, interaction terms between competition and technology will be included to test the third hypothesis. The three hypotheses are nested in the sense that the specification for Hypothesis 3 also allows to test Hypotheses 1 and 2. The results in the first three sections are derived from OLS regressions that control for country-time and industry fixed effects and Section 4.4 discusses the results from probit regressions.

\footnotetext{
${ }^{4}$ See Table 4 for a description of all variables and Table 2 for summary statistics.
} 


\subsection{Do technologically advanced firms innovate more?}

The first hypothesis states that more advanced firms have more product innovations than less advanced firms. The reason is that frontier firms innovate themselves, while firms further away from the frontier can imitate the frontier technology and therefore innovate less. To test this at the firm level, two dummy variables for leaders (with more advanced technology than their main competitor) and leveled firms (with the same level of technology as their main competitor) are included as explanatory variables. This leads to the following specification:

$$
\text { ProdInno }=\alpha_{0}+\alpha_{1} \text { Leader }+\alpha_{2} \text { Leveled }+\alpha_{3} \bar{m}+\alpha_{4} \bar{m}^{2}+\boldsymbol{X} \boldsymbol{\alpha}_{\mathbf{5}}+\epsilon .
$$

$\boldsymbol{X}$ is a vector containing the remaining observed firm characteristics and country-time and industry fixed effects, and $\epsilon$ is an error term with zero expected value conditional on firm characteristics. Leader and Leveled are the two dummy variables for the two higher levels of technology and the omitted category consists of firms that have less advanced technology than their main competitors. $\bar{m}$ measures competition in the industry and the country in which the firm is located. Higher values of $\bar{m}$ correspond to lower average market power and higher competition.

The results are presented in Column 1 of Table 5, which shows strong evidence in support of Hypothesis 1. The coefficients of Leader and Leveled are positive and significant and the one for Leader is larger. The interpretation of these coefficients is that being a leader or a leveled firm as opposed to a laggard is positively correlated with innovation. The remaining columns show the results when alternative measures of competition are used. The estimates of the competition variables will be discussed in more detail in the next section, but it can be seen from Table 5 that, irrespective of how competition is measured, leaders and leveled firms always innovate significantly more than laggards.

\subsection{Inverted- $U$ relationship between innovation and competition}

The second hypothesis is based on the main prediction from the model in Aghion et al. (2005). Their empirical investigation using a panel of UK firms shows an inverted-U relationship between competition and innovation. To investigate this, we start with the specification in Equation 1, where a square term of competition is included to allow for a nonlinear relationship. The alternative measures of competition will then be discussed separately in the following sections. 


\section{Competition measured as average market power}

The first column of Table 5 shows the results of estimating Equation 1. There is evidence that competition is more positively correlated with product innovation at low levels of competition. This can be seen from the positive coefficient of the linear term and the negative square term. But the peak is at a relatively high level of competition and the negative square term never compensates the linear term on the scale of competition from one to four. In this specification, a marginal increase in competition at high levels of competition therefore does not seem to be associated with a decrease in product innovation as would be suggested by the inverted-U hypothesis. However, the results do show that competition is more positively related to innovation when the initial level of competition is low.

\section{The distribution of market power}

A concern in Equation 1 may be that market power is measured on an ordinal scale and that the average across the four categories of market power therefore is difficult to interpret. Furthermore, the average does not capture the distribution of firms across the different levels of market power. One possibility to take theses two issues into account is to use the fraction of firms in an industry and country at each level of market power. This is calculated as $\bar{M}_{1 c, s}=\frac{1}{N_{c, s}} \sum_{i \in c, s} M_{1}(i)$, where $M_{1}(i)$ is a binary variable that takes value one if firm $i$ has the market power level one and $N_{c, s}$ is the number of firms in the same country $c$ and industry $s$ as firm $i$. The analogous calculation applies to the three remaining market power levels $M_{2}, M_{3}$, and $M_{4}$. The four averages together characterize the distribution of the firms across the different levels within an industry and country. For an individual firm $i, \bar{M}_{1}(i), \bar{M}_{2}(i), \bar{M}_{3}(i)$, and $\bar{M}_{4}(i)$ capture the fractions of firms in the same country and industry that have each level of market power, which is used in the following specification:

$$
\text { ProdInno }=\beta_{0}+\beta_{1} \text { Leader }+\beta_{2} \text { Leveled }+\beta_{3} \bar{M}_{1}+\beta_{4} \bar{M}_{2}+\beta_{5} \bar{M}_{3}+\boldsymbol{X} \boldsymbol{\beta}_{6}+\epsilon
$$

The coefficient $\beta_{3}$ now captures how much the product innovation index of firm $i$ changes when the fraction of firms with high market power increases. The analogous interpretation applies to $\beta_{4}$ and $\beta_{5} . \bar{M}_{4}$ is omitted because the four fractions add up to one such that $\bar{M}_{4}$ is a linear combination of the other three fractions. The ceteris paribus interpretation is that a change in each of the variables $\bar{M}_{1}, \bar{M}_{2}$, or $\bar{M}_{3}$ always has an 
opposite change in the omitted variable $\bar{M}_{4}$, because the other two fractions remain constant. An alternative interpretation is that firms shift across all levels of market power, i.e. firms in category four move to category three, and some of the firms in that category also move to higher levels such that the fraction of firms at that level remains constant. With both interpretations, an increase in one of the three levels implies higher average market power and a decrease in competition.

In the context of Figure ??, an increase in $\bar{m}$ in Equation 1 is equivalent to moving on the x-axis to the right. With the specification in Equation 2, an increase in $\bar{M}_{1}, \bar{M}_{2}$ or $\bar{M}_{3}$ always implies a decrease in competition, since the fraction of firms with high market power is increased and the one with low market power is reduced. In Figure ??, this consequently would mean going along the x-axis from the right to the left. Another difference to the previous specification is that, by including each level of market power separately, the specification allows for a nonlinear relationship between competition and innovation, since an increase in each level can have a different correlation with product innovation. Hypothesis 2 would be supported if $\bar{M}_{2}$ and $\bar{M}_{3}$, which capture an increase in the fraction of firms with intermediate market power, had positive estimates and higher absolute values than the one of $\bar{M}_{1}$. Positive estimates show that increasing intermediate market power (and correspondingly decreasing the fraction of firms with the lowest market power $M_{4}$ ) is associated with an increase in product innovation. Estimates for $\bar{M}_{2}$ and $\bar{M}_{3}$ above the one for $\bar{M}_{1}$ would suggest that having intermediate market power relative to no market power is more beneficial in terms of innovation than having high market power relative to no market power.

The second column in Table 5 presents the results from estimating Equation 2. All coefficients for the three levels are positive, which suggests that having one of the three market power levels is always better than not having any market power (the omitted category). Furthermore, the second highest level of average market power has the highest value and this provides some evidence for an inverted-U relationship between competition and innovation.

\section{Weighted average market power}

Another approach to derive a measure for competition from the market power of individual firms is to weight market power by firm size. This may be appropriate because a large firm has a stronger impact on the competitiveness of the market than a small firm. Average market power then is calculated as $\tilde{m}_{c, s}=\frac{1}{N_{c, s}} \sum_{i \in c, s} m(i) \frac{e(i)}{\bar{e}_{c, s}}$, where $e(i)$ is the size of firm $i$ in terms of employment and $\bar{e}_{c, s}$ is the average employment in the country 
and industry. The same calculation as above also leads to $\tilde{M}_{1 c, s}=\frac{1}{N_{c, s}} \sum_{i \in c, s} M_{1}(i) \frac{e(i)}{\bar{e}}$ and the fractions for the other levels.

The problem with this approach is that, when looking at an average firm, giving higher weights to larger firms (that also tend to have higher market power) would reduce the measure for competitive pressure on the average firm. This would not be consistent with the increase in actual pressure that arises from having a more powerful competitor. Furthermore, the weighted average may confuse the effects of market power and size on innovation, because larger firms are also more likely to innovate. Thus, the weighted and the unweighted market power averages both have disadvantages, but finding similar results with both measures would strengthen the credibility of both measures.

The third and fourth columns in Table 5 show the results of estimating Equations 1 and 2 with weighted averages. The support for the inverted-U hypothesis is weaker when using weights, since the significance of the linear term and the square term is lower with the continuous measure of competition in Equation 1. When the weighted fractions for each level of market power are used in Equation 2, then the third level has the highest coefficient, but the second one is significantly lower and almost equal to the highest level. Overall, the evidence for the inverted-U hypothesis and a nonlinear relationship is weaker when using weights, but the results point in the same direction.

\section{Firm level market power}

Instead of aggregating firms' market power to the industry and country level, this section focuses on the market power of individual firms and relates this to their innovative activities. This approach is subject to a more severe endogeneity problem, since firms may have market power because they innovated. Nonetheless, it is interesting to compare these correlations to the aggregated competition measure. The results of estimating Equation 2 with the firm level variables $M_{1}, M_{2}$, and $M_{3}$ instead of the averages are reported in the fifth column of Table 5 . The results are qualitatively similar to before: There is some evidence suggesting an inverted- $U$ relationship between innovation and market power, since the second highest level of market power features a slightly stronger correlation, but the inverted- $\mathrm{U}$ is skewed towards high market power. 


\subsection{Is competition more positively correlated with innovation in technologically advanced firms?}

Hypothesis 3 states that leaders and leveled firms feature a more positive relationship between innovation and competition than laggards. One reason is that their activities require more skills, which are fostered by competition. An alternative explanation is that advanced firms respond to an increase in competition by innovating, because this allows them to escape their competitors. $\bar{m}$ and $\bar{m}^{2}$ in Equation 1 are therefore interacted with the two technology levels:

$$
\begin{aligned}
\text { ProdInno } & =\alpha_{0}+\alpha_{1} \text { Leader }+\alpha_{2} \text { Leveled }+\alpha_{3} \bar{m}+\alpha_{4} \bar{m}^{2} \\
& +\alpha_{5} \text { Leader } * \bar{m}+\alpha_{6} \text { Leveled } * \bar{m} \\
& +\alpha_{7} \text { Leader } * \bar{m}^{2}+\alpha_{8} \text { Leveled } * \bar{m}^{2} \\
& +\boldsymbol{X} \boldsymbol{\alpha}_{\mathbf{9}}+\epsilon .
\end{aligned}
$$

The variables of interest for Hypothesis 3 are the interaction terms between the market power and technology levels. $\alpha_{5}$ measures the difference between leaders and laggards in their respective correlation between competition and product innovation. $\alpha_{6}$ captures the same difference between leveled firms and laggards. The coefficients $\alpha_{7}$ and $\alpha_{8}$ show the differences with respect to the curvature, i.e. how much the correlation between innovation and competition changes in the level of competition compared to a laggard. Aghion et al. (2005) predict that leveled firms are affected the most positively by competition and that the increasing side of the inverted- $U$ is steeper, as is also seen in Figure ??. Therefore, the interaction term Leveled $* \bar{m}$ is expected to be positive and Leveled $* \bar{m}^{2}$ negative. In the context of Acemoglu, Aghion and Zilibotti (2006), leaders should feature a more positive correlation between competition and innovation than laggards because they rely the most on innovation and this would predict that $\alpha_{5}$ is also positive.

Column 1 in Table 6 shows the results of estimating Equation $3 .{ }^{5}$ The reference group, consisting of laggards, does not show a significant correlation between average market power and product innovation. This can be seen from the coefficients of $\bar{m}$ and $\bar{m}^{2}$. Being a leader does not significantly differ from being a laggard when competition is zero, as

\footnotetext{
${ }^{5}$ The analysis is not repeated for market power at the firm level, because interacting a firm's technology with its market power would not allow a meaningful interpretation. The results using the weighted averages instead of normal averages are less significant. This may be due to the reasons outline above and the results are not reported here.
} 
is shown by the insignificant dummy variable for leader. Although the value of zero does not exist on the scale for competition used here, it would imply an extremely low level of competition. The result that leaders do not innovate more than laggards at this extremely low level of competition, thus, is consistent with the theory. The interactions with market power are also insignificant and this would suggest that leaders do not benefit more from competition than laggards, which is not in line with the hypothesis. The signs are as expected and adding up the individual terms and the interaction terms (at the average market power of 2.52) leads to a positive number, but there is still only weak evidence that leaders innovate more.

The estimates for leveled firms are more significant and consistent with the hypothesis. The negative coefficient for Leveled shows that firms that are at the same technology level as their competitors innovate less than laggards if industry competition is zero. This is again consistent with the theory, because a leveled firm does not innovate more (or even innovates less) than a laggard when competition is extremely low. But as competition increases, it has a stronger effect on leveled firms than on laggards. This is shown by the interaction with $\bar{m}$, which suggests a higher correlation between competition and innovation for leveled firms compared to laggards. The negative interaction with $\bar{m}^{2}$ indicates that the curve is steeper for a leveled firm. The result from estimating Equation 3 therefore provides some support for Hypothesis 3, in particular with respect to the prediction in Aghion et al. (2005) that leveled firms respond to competition the most positively. However, at average market power, the negative coefficients of Leveled and Leveled $* \bar{m}^{2}$ are just barely compensated by the positive coefficient of $\bar{m}$. This would imply that leveled firms innovate about as much as laggards at average levels of competition and only do better at high levels of competition. ${ }^{6}$

Testing Hypothesis 3 with the categorical measures of competition in Equation 2 requires to interact Leader and Leveled with each of the three categories. This leads to

\footnotetext{
${ }^{6}$ The explanation in Aghion et al. (2005) for why leveled firms innovate the most is that leaders may, to some extent, be protected from competition by their superior technology level and are therefore not affected by an increase in competition. This interpretation of Leader, Leveled, and Laggard in the data set differs from the previous assumption that the three levels of technology capture different distances to the technology frontier. The rationale for that interpretation was the expectation that firms answer this question by comparing themselves to the average firm in the industry and a leveled firm thus would be somewhere between a leader and a laggard. But the results above would suggest a more literal interpretation of the question, namely that leveled firms are at the same technological level as their main (most advanced) competitor. Such leveled firms then have the possibility to escape competition, which may give them stronger incentives to innovate than leaders which are protected by their more advanced technology.
} 
the following specification:

$$
\begin{aligned}
\text { ProdInno } & =\beta_{0}+\beta_{1} \text { Leader }+\beta_{2} \text { Leveled }+\beta_{3} \bar{M}_{1}+\beta_{4} \bar{M}_{2}+\beta_{5} \bar{M}_{3} \\
& +\beta_{6} \text { Leader } * \bar{M}_{1}+\beta_{7} \text { Leader } * \bar{M}_{2}+\beta_{8} \text { Leader } * \bar{M}_{3} \\
& +\beta_{9} \text { Leveled } * \bar{M}_{1}+\beta_{10} \text { Leveled } * \bar{M}_{2}+\beta_{11} \text { Leveled } * \bar{M}_{3} \\
& +\boldsymbol{X} \boldsymbol{\beta}_{\mathbf{1 2}}+\epsilon .
\end{aligned}
$$

This specification needs to be interpreted differently from the previous one. The coefficients of the three fractions of market power for each level $\left(\beta_{3}, \beta_{4}\right.$, and $\left.\beta_{5}\right)$ show the correlation between product innovation and competition for the reference group consisting of laggards. The coefficients of Leader and Leveled capture the correlation of these technology levels with innovation if $\bar{M}_{1}, \bar{M}_{2}$, and $\bar{M}_{3}$ are zero. This implies that $\bar{M}_{4}$ is one and that there are no firms with any market power. According to Hypothesis 3, we expect leaders and leveled firms to innovate more at this high level of competition. But as average market power increases and competition decreases, the advantage of leaders and leveled firms should be reduced, because lower levels of competition imply less skills and this harms their innovative activities. Furthermore, leveled firms have less incentives to innovate at low levels of competition, since they already have high rents before innovating.

The second column in Table 6 shows the results for Equation 4. There is no robust pattern and only weak evidence supporting Hypothesis 3. Although all interaction terms are negative as expected, only two of them are significant. The significance of the interaction between Leveled and $\bar{M}_{1}$ is in line with Aghion et al. (2005). However, it is less clear why leaders have an even more negative interaction term with $\bar{M}_{2}$. There is, therefore, substantial uncertainty attached to the results for Hypothesis 3.

\subsection{Robustness to nonlinear specification}

The innovation index used above is constructed in such a way that it takes the values zero if a firm has neither introduced a new product nor upgraded an existing product, one if a firm has undertaken only one of the two measures, and two if it has undertaken both. In the previous specifications, this index was estimated with a linear model. But since the dependent variable is categorical, the magnitude of the change in this variable that is associated with a change in one of the independent variables depends on the levels of the independent variables. The appropriate way to estimate this would be to use a nonlinear model. In this section, I focus on the binary variable NewProd as one 
of the components of the index to estimate a nonlinear probability model. This variable takes the value of one if a firm introduced a new product during the last three years and zero if it did not. The nonlinear model is estimated with a probit regression similarly to Almeida and Fernandes (2008) and the results are reported in Tables 7 and 8.

The estimates for the first two hypotheses are similar to the linear model. The most important difference is that being a leveled firm is not significantly different from a laggard anymore. For the third hypothesis the evidence now is even weaker, since none of the interactions are significant with the categorical measure. ${ }^{7}$ However, the results are similar to the linear model when using the normal average and a square term, namely that leveled firms seem to benefit significantly more from competition than laggards.

\section{Extension to country income groups}

The empirical analysis so far was a cross-section estimation with fixed effects for countries and industries. The underlying assumption therefore was that different countries and industries may have different levels of product innovation, but the correlation of innovation with the explanatory variables was assumed to be the same across the countries and industries. The purpose of this section is to analyze the relationships individually for different income groups of countries. The rationale for this is that the economic development of the country affects how firms respond to competition and how competition interacts with the technology level of the firm. The first point follows directly from the distance to frontier argument in Acemoglu, Aghion and Zilibotti (2006): In low-income countries, firms do not rely as much on innovation, and competition hence has a less beneficial effect on them. The second point is due to the importance of different technology frontiers. Bartelsman, Haskel and Martin (2008) provide evidence showing that firms which are far behind the technology frontier are not affected by the global frontier, but that they are affected by the national frontier. A possible reason for this is that technology from the global frontier is not compatible with the knowledge in these firms if they are too far away. In the paper here, the distance to frontier measure is based on the comparison of a firm's technology to its main competitor. In less developed countries, this competitor is likely to be geographically close. Consequently, this measure can be expected to be more important relative to the global frontier in countries further away

\footnotetext{
${ }^{7} \mathrm{Ai}$ and Norton (2003) show that interaction terms in probit models may not yield the true effects and require a different calculation. But since the result is already ambiguous for the first approach, I do not further consider this.
} 
from the frontier. For the same reason, in such countries it should also have a larger impact on the relationship between competition and innovation.

The Tables 9 and 10 show the results for the first two hypotheses separately for each of the three country income groups in the sample and Tables 11 and 12 report the results for the third hypothesis. ${ }^{8}$ The pattern is not exactly as expected, since the lowest income group does not have stronger correlations. However, the lower-middle income group features most of the relationships that are expected and there is support for the three hypothesis in these countries. ${ }^{9}$ In lower-middle income countries (Column 2 in Tables 9 and 10), leaders innovate more and there is evidence of a nonlinear relationship between competition and innovation. When interaction terms are included in Table 12, then there is an inverted- $\mathrm{U}$ relationship between innovation and competition for the base category of laggards. Secondly, at the maximum level of competition (when $\bar{M}_{4}$ equals one), being a leader or a leveled firm is associated with significantly more innovation compared to a laggard. Thirdly, the negative interaction terms show that, as the fractions of firms with market power increase, leaders and leveled firms experience a larger decrease in innovation than laggards.

The results are different when looking at the other income groups and there seems to be no clear pattern that holds across all groups. A potential reason why there is such strong support for the hypotheses in lower-middle income countries (and not as expected in the low income group), is that firms in these countries are particularly heterogeneous with respect to their response to competition. Carlin, Schaffer, and Seabright (2004) point out that market oriented firms may coexist with older firms that were founded under a less market based system. This is particularly the case in the region of Eastern Europe and Central Asia, where $61 \%$ of the firms in the sample are located. In such a setting, the technology compared to the main competitor may have a stronger impact on the relationship between competition and innovation, because firms that perceive themselves to be more advanced are likely to be more market oriented and also respond to competition more positively.

\footnotetext{
${ }^{8}$ Only the three lowest income groups are in the sample. Firms from high income and OECD countries are either excluded or do not have the relevant information.

${ }^{9}$ To this group belong, according to the classification by the World Bank, Albania, Armenia, Belarus, Bosnia and Herzegovina, Brazil, Bulgaria, Ecuador, El Salvador, Macedonia, Guatemala, Honduras, Indonesia, Kazakhstan, Romania, Russia, Serbia and Montenegro, Syria, Turkey, and Ukraine.
} 


\section{Conclusion}

The purpose of this paper was to analyze how firms' product innovation is related to their distance to the technology frontier and to industry competition. The results from the analysis of survey data show that firms that have more advanced technology than their main competitor innovate more than firms with less advanced technology. The second result is that an increase in competition is associated with a larger increase in innovation if the initial level of competition is low. Whether there is a level of competition after which a further increase would reduce innovation (an inverted-U relationship between competition and innovation), depends on how competition is measured. The third finding is that the level of technology can matter for the correlation between competition and innovation, but there is no robust pattern. In some cases, firms that are more advanced than their competitors feature the strongest correlation between competition and product innovation. When a different measure for competition is used, then firms that are at the same level as their competitors seem to benefit the most from competition. Yet in other cases, there is no significant difference to firms that are less advanced.

To summarize, the relationship between competition and innovation depends both on the level of competition and the level of technology. However, the evidence does not allow to identify the levels at which these relationships are strongest and there are substantial differences between countries. One reason why it may be difficult to identify robust correlations between innovation, competition, and technology could be their dependence on other factors. The large differences which can be found between countries at different stages of development may be partly due to certain characteristics that are specific to their development stage and which have an impact on the relationship between innovation, competition and technology within firms. The aggregate level of technology of the country (the national technology frontier) is one such characteristic. Further factors affecting the link between innovation and competition are related institutions such as financial markets or the legal system. The data set provides a rich set of indicators of the business environment that allow to study the importance of these factors. Further research focusing on the differences between countries with respect to the business environment may shed more light on how they affect the relationship between innovation, competition, and technology. 


\section{References}

Acemoglu, Daron, Philippe Aghion, and Fabrizio Zilibotti (2006): "Distance to Frontier, Selection, and Economic Growth." Journal of the European Economic Association. Vol. 4, Issue 1, pp. 37 - 74.

Aghion, Philippe, Richard Blundell, Rachel Griffith, Peter Howitt, and Susanne Prantl (2006): "The Effects of Entry on Incumbent Innovation and Productivity." NBER Working Paper 1202\%.

Aghion, Philippe, Nick Bloom, Richard Blundell, Rachel Griffith and Peter Howitt (2005): "Competition and Innovation: An Inverted-U Relationship." The Quarterly Journal of Economics, Vol. 120, No. 2, pp. 701-728.

Aghion, Philippe and Rachel Griffith (2005): "Competition and growth: reconciling theory and evidence." MIT Press, Cambridge, Mass.

Ai, Chunrong and Edward C. Norton (2003): "Interaction terms in logit and probit models "Economics Letters, Volume 80, Issue 1, pp. 123-129

Almeida, Rita and Ana Margarida Fernandes (2008): "Openness and Technological Innovations in Developing countries: Evidence from Firm-Level Surveys." Journal of Development Studies. Vol. 44, No. 5, pp. 701-727.

Bartelsman, Eric, Jonathan Haskel and Ralf Martin (2008): "Distance to Which Frontier? Evidence on Productivity Convergence from International Firm-level Data." CEPR Discussion Paper No. DPr032.

Blundell, Richard, Rachel Griffith and John Van Reenen (1999): "Market Share, Market Value and Innovation in a Panel of British Manufacturing Firms." Review of Economic Studies, Vol 66, pp. 529 - 554.

Carlin, Wendy, Mark Schaffer and Paul Seabright (2004): "A Minimum of Rivalry: Evidence from Transition Economies on the Importance of Competition for Innovation and Growth." University of Michigan Business School, Davidson Institute Working Paper Series, No. 670.

Coad, Alex (2008): "Distance to Frontier and Appropriate Business Strategy." Paper presented at the 25th Celebration Conference 2008 on Entrepreneurship and Innovation - 
Organizations, Institutions, Systems and Regions, Copenhagen, CBS, Denmark, June 17 - 20, 2008.

Nickell, Stephen J. (1996): "Competition and Corporate Performance." Journal of Political Economy, Vol. 104, No. 4

World Bank (2002): "Productivity and the Investment Climate: Private Enterprise Survey."

World Bank (2007a): "Enterprise Surveys: Understanding the Sampling Methodology." Available at: https://www. enterprisesurveys.org/documents/Sampling_ Note. pdf

World Bank (2007b): "Enterprise Surveys: Understanding the Questionnaire." Available at: https://www. enterprisesurveys.org/documents/Questionnaire_note_ January_2007. pdf 


\section{A Data description}

The World Bank Enterprise Survey project began in 2002 and currently includes 86'000 observations from 110 countries. In each country, firms are surveyed every three to five years with a questionnaire that includes country-specific questions and a set of standardized questions that are comparable across all countries. The survey mainly focuses on private businesses and selects between 250 and 1'500 firms per country and year based on a simple random or stratified random methodology. After dropping firms that did not report innovation and market power, 22'000 firms are left. When the data set is further restricted to firms that also report their technology level, about 9'000 firms from 40 countries remain in the sample. Europe and Central Asia with 6'000 firms is the largest region in this sample in terms of interviewed firms, followed by Latin America and the Caribbean with 2'000. Almost half of the firms are from the manufacturing sector, followed by the service sector.

\section{Technology, market power, and innovation}

The three key variables for this study are the technology of a firm compared to its main competitor, market power (or competition), and innovation. These variables and their relationship will be discussed separately in the following sections.

\section{Technology compared to the main competitor}

Firms were asked the following question about their technology: "Thinking of your main product line or main line of services and comparing your production process with that of your closest competitor, which of the following best summarizes your position: (select one) 1. My firm's technology is less advanced than that of its main competitor, 2. My firm's technology is about the same as that of its main competitor, 3. My firm's technology is more advanced than that of its main competitor." (World Bank (2002: 8)) The important feature here is that technology is always compared with another firm that is perceived to be the main competitor. This firm may be domestic or foreign and it can have different levels of technology. It therefore does not represent the global technology frontier in terms of productivity, but rather the frontier on the relevant market. From this question about technology, I construct three dummy variables Laggard, Leveled, and Leader for each of the technology levels 1, 2, and 3. From the firms that state their technology level, 1'400 are laggards, 5'300 are leveled firms, and 2'300 perceive themselves to be leaders. 


\section{Market power and competition}

Market power is captured by a simplified hypothetical monopolist test. Respondents could choose between four answers: "If you were to raise your prices of your main product line or main line of services $10 \%$ above their current level in the domestic market (after allowing for any inflation) which of the following would best describe the result assuming that your competitors maintained their current prices? (select one of the options below). 1. Our customers would continue to buy from us in the same quantities as now, 2. Our customers would continue to buy from us, but at slightly lower quantities, 3. Our customers would continue to buy from us, but at much lower quantities, 4. Our customers would stop buying from us." (World Bank (2002: 3)) Category 1 corresponds to the highest market power and category 4 to the lowest. Table 1 shows the frequencies of the levels of market power overall and separately for leaders, leveled firms, and laggards. Not surprisingly, firms with less advanced technology also have less market power. Firms with technology that is about at the same level as their competitors' technology show a similar pattern as the less advanced firms. This is to be expected, because having competitors at the same level clearly increases the competitive pressure. Significantly different from the other two groups are the leaders. The largest fraction among this group reports that they would sell slightly lower quantities, while the other three categories are almost equally frequent.

Table 1: Percentage of firms at different market power and technology levels

\begin{tabular}{lrrrr}
\hline \hline & \multicolumn{4}{c}{ Firm's technology relative to main competitor } \\
Customer reaction & less advanced & about the same & more advanced & Total \\
\hline same quantities & 13.46 & 14.04 & 21.85 & 15.97 \\
slightly lower & 27.70 & 30.41 & 32.44 & 30.51 \\
much lower & 24.40 & 25.31 & 21.90 & 24.29 \\
stop buying & 34.43 & 30.24 & 23.81 & 29.23 \\
Total & 100.00 & 100.00 & 100.00 & 100.00 \\
\hline $\mathrm{N}$ & 1,426 & 5,314 & 2,352 & 9,092 \\
\hline \hline
\end{tabular}

\section{Product innovation and upgrading}

Firms were asked the following question about their activities regarding innovation and restructuring: "Has your company undertaken any of the following initiatives in the last three years? 1. Developed a major new product line, 2. Upgraded an existing prod- 
uct line, 3. Introduced new technology that has substantially changed the way that the main product is produced, 4. Discontinued at least one product (not production) line, 5. Opened a new plant, 6. Closed at least one existing plant or outlet, 7 . Agreed a new joint venture with foreign partner, 8. Obtained a new licensing agreement, 9. Outsourced a major production activity that was previously conducted in-house, 10. Brought in-house of a major production activity that was previously outsourced." Three key features of these measures of innovation and restructuring should be stressed. Firstly, given that respondents were asked to distinguish a number of different initiatives, the particular characteristics of each initiative can be interpreted more precisely. Especially the distinction between product innovation and technology innovation will be important for the empirical assessment. Secondly, the question captures the output in terms of innovation and restructuring, rather than the input in terms of investments. On the one hand, this is an advantages of this measure, since we are really interested in output and not in input. On the other hand, output is difficult to quantify and stating whether a certain initiative has been undertaken does not say much about its significance or economic value. Thirdly, the rather long and backward looking perspective over three years makes it difficult to assess what actually drives innovation, since most of the remaining questions focus on the current state of the firm.

Table 2 shows the fraction of firms that developed a new product, upgraded an existing product, and introduced new technology. Almost half of the firms developed a new product and roughly two thirds upgraded a product. Also a substantial fraction of firms introduced new technology. The innovation index constructed from the first two binary variables takes the maximum value of two if both measures were undertaken, one if only one of the two was undertaken, and zero if none of them was undertaken. The index is constructed in such a way that an increase by one unit corresponds roughly to one additional initiative.

It is important to define how this index should be interpreted. Although the first question specifically asks about the development of a new product, firms may still report an introduction of products that are new to the firm, but not necessarily to the rest of the industry, as product innovation or upgrading. The index thus captures the expansion or improvement of the product line through innovation and to some extent also through imitation. Consequently, no clear distinction can be made between innovation and imitation like in Acemoglu, Aghion and Zilibotti (2006) and the index will be referred to as product innovation in the sections that follow.

To see how innovation relates to market power and technology at the firm level, Table 
Table 2: Firm characteristics

\begin{tabular}{llllll}
\hline \hline & $\mathrm{N}$ & mean & $\mathrm{SD}$ & $\min$ & $\max$ \\
\hline NewProd & 22433 & 0.37 & 0.48 & 0.00 & 1.00 \\
UpgrProd & 22433 & 0.54 & 0.50 & 0.00 & 1.00 \\
ProdInno & 22433 & 0.91 & 0.83 & 0.00 & 2.00 \\
NewTechn & 22272 & 0.34 & 0.47 & 0.00 & 1.00 \\
$m$ & 22433 & 2.62 & 1.09 & 1.00 & 4.00 \\
Leader & 9092 & 0.26 & 0.44 & 0.00 & 1.00 \\
Leveled & 9092 & 0.58 & 0.49 & 0.00 & 1.00 \\
Laggard & 9092 & 0.16 & 0.36 & 0.00 & 1.00 \\
Age & 22433 & 15.77 & 17.16 & 0.00 & 202.00 \\
employment & 22433 & 116.39 & 643.82 & 0.02 & 70087.00 \\
PrivFirm & 22433 & 0.93 & 0.26 & 0.00 & 1.00 \\
EducWorkforceUni & 22433 & 24.67 & 28.47 & 0.00 & 100.00 \\
Exporter & 22433 & 0.24 & 0.43 & 0.00 & 1.00 \\
Importer & 22433 & 0.48 & 0.50 & 0.00 & 1.00 \\
\hline \hline
\end{tabular}

3 reports the average deviation of a firms' product innovation from the industry and country mean separately for each level of market power and technology. ${ }^{10}$ We observe that leaders with intermediate market power innovate substantially more than average. Laggards always innovate less than their industry average, while leveled firms also are less likely to innovate than the average unless they enjoy upper-intermediate market power. With respect to market power alone, we see that there is some evidence for a concave relationship: at the highest level, firms innovate only slightly more than average, while they innovate substantially more at upper-intermediate levels. Firms with lower-intermediate market power or no market power innovate less than firms with upper-intermediate market power and this is true for all three groups. There seems to be an inverted-U, but it is skewed towards high levels of market power.

\section{Other firm characteristics}

The questionnaire of the Enterprise Surveys includes a large amount of information about firms and their perception of the business environment. Many of these variables are important to control for when analyzing the relationship between product innovation, market power and technology, because they may be correlated with several of them. The first set of firm characteristics that I control for consists of age and size of the firm. Large

${ }^{10}$ Deviations from the country-industry average are used in order to control for country-industry fixed effects. 
Table 3: Average product innovation per market power and technology levels (deviations from country-industry mean)

\begin{tabular}{lrrrr}
\hline \hline & \multicolumn{4}{c}{ Firm's technology relative to main competitor } \\
Customer reaction & less advanced & about the same & more advanced & Total \\
\hline same quantities & -0.13 & -0.03 & 0.16 & 0.02 \\
slightly lower & -0.00 & 0.02 & 0.23 & 0.08 \\
much lower & -0.13 & -0.01 & 0.12 & -0.00 \\
stop buying & -0.15 & -0.08 & 0.12 & -0.05 \\
Total & -0.10 & -0.02 & 0.17 & 0.01 \\
\hline $\mathrm{N}$ & 1,426 & 5,314 & 2,352 & 9,092 \\
\hline \hline
\end{tabular}

firms can exploit economies of scale in R\&D and they have a broader range of products, such that we expect them to have a higher likelihood to introduce a new product. As often seen in the related literature, I use the logarithm of the number of employees as a measure for size. Conditional on size, older firms are less likely to innovate. Table 2 shows that the average age is 16 years and the average number of employees is 130, such that the typical firm in the sample tends to be rather large and established. From a development perspective, this could be problematic, because in less developed countries there are more small and informal businesses that are not captured by the survey.

The second type of firm characteristics is the ownership structure of firms and how they are integrated in international trade. Table 2 shows that the majority of firms is privately and domestically owned. Although foreign ownership is only $10 \%$ on average, exposure to foreign economies is fairly common, since more than half of the firms import and almost one quarter exports. The last kind of firm characteristics that I consider is education. Skills are more important for innovation than for imitation and they become increasingly crucial for a firm's performance when the frontier is being approached. On average $24 \%$ hold a university degree and almost $70 \%$ of the workforce has at least 10 years of education. This average is about $8 \%$ higher for leader firms compared to laggards, indicating that education is more important for advanced firms. 
Table 4: Description of the main variables (firm level)

\begin{tabular}{|c|c|}
\hline Variable Name & Description \\
\hline NewProd & Dummy for "Introduced new product line" \\
\hline UpgrProd & Dummy for "Upgraded an existing product line" \\
\hline ProdInno & Index from NewProd + UpgrProd \\
\hline$M_{1}$ & $\begin{array}{l}\text { Dummy for "Our customers would continue to buy from us in the } \\
\text { same quantities as now" }\end{array}$ \\
\hline$M_{2}$ & $\begin{array}{l}\text { Dummy for "Our customers would continue to buy from us, but at } \\
\text { slightly lower quantities" }\end{array}$ \\
\hline$M_{3}$ & $\begin{array}{l}\text { Dummy for "Our customers would continue to buy from us, but at } \\
\text { much lower quantities" }\end{array}$ \\
\hline$M_{4}$ & Dummy for "Our customers would stop buying from us" \\
\hline $\bar{M}_{1}$ & Fraction of firms in the same country and industry that have $M_{1}=1$ \\
\hline $\bar{M}_{2}$ & Fraction of firms in the same country and industry that have $M_{2}=1$ \\
\hline $\bar{M}_{3}$ & Fraction of firms in the same country and industry that have $M_{3}=1$ \\
\hline $\bar{M}_{4}$ & Fraction of firms in the same country and industry that have $M_{4}=1$ \\
\hline$\tilde{M}_{1}$ & $\begin{array}{l}\text { Weighted fraction of firms in the same country and industry that } \\
\text { have } M_{1}=1\end{array}$ \\
\hline$\tilde{M}_{2}$ & $\begin{array}{l}\text { Weighted fraction of firms in the same country and industry that } \\
\text { have } M_{2}=1\end{array}$ \\
\hline$\tilde{M}_{3}$ & $\begin{array}{l}\text { Weighted fraction of firms in the same country and industry that } \\
\text { have } M_{3}=1\end{array}$ \\
\hline$\tilde{M}_{4}$ & $\begin{array}{l}\text { Weighted fraction of firms in the same country and industry that } \\
\text { have } M_{4}=1\end{array}$ \\
\hline$m$ & Ordinal scale for $M_{1}, M_{2}, M_{3}$, and $M_{4}$. \\
\hline $\bar{m}$ & Mean of $m$ across all firms in the same industry and country \\
\hline$\tilde{m}$ & $\begin{array}{l}\text { Weighted mean of } m \text { across all firms in the same industry and } \\
\text { country }\end{array}$ \\
\hline Leader & $\begin{array}{l}\text { Dummy for firms that have more advanced technology than } \\
\text { competitors }\end{array}$ \\
\hline Leveled & $\begin{array}{l}\text { Dummy for firms that have about the same technology as } \\
\text { competitors }\end{array}$ \\
\hline Laggard & $\begin{array}{l}\text { Dummy for firms that have less advanced technology than } \\
\text { competitors }\end{array}$ \\
\hline Age & Age of the firm \\
\hline employment & Number of employees \\
\hline PrivFirm & Dummy for firms that are to more than $50 \%$ owned privately \\
\hline EducWorkforceUni & Percentage of workforce with more than 12 years education \\
\hline Exporter & $\begin{array}{l}\text { Firms that exports either directly or indirectly some of their } \\
\text { products }\end{array}$ \\
\hline Importer & Firms that either import directly or indirectly some of their material \\
\hline
\end{tabular}


B Regression tables 
Table 5: Product innovation

\begin{tabular}{|c|c|c|c|c|c|}
\hline Leader & $\begin{array}{c}(1) \\
0.213^{* * *} \\
(8.66)\end{array}$ & $\begin{array}{c}(2) \\
0.213^{* * *} \\
(8.68)\end{array}$ & $\begin{array}{c}(3) \\
0.214^{* * *} \\
(8.71)\end{array}$ & $\begin{array}{c}(4) \\
0.215^{* * *} \\
(8.74)\end{array}$ & $\begin{array}{c}(5) \\
0.208^{* * *} \\
(8.45)\end{array}$ \\
\hline Leveled & $\begin{array}{c}0.0462^{* *} \\
(2.13)\end{array}$ & $\begin{array}{c}0.0469^{* *} \\
(2.17)\end{array}$ & $\begin{array}{c}0.0474^{* *} \\
(2.18)\end{array}$ & $\begin{array}{c}0.0476^{* *} \\
(2.19)\end{array}$ & $\begin{array}{c}0.0449^{* *} \\
\quad(2.07)\end{array}$ \\
\hline $\bar{m}$ & $\begin{array}{c}0.526^{* *} \\
(2.28)\end{array}$ & & & & \\
\hline $\bar{m}^{2}$ & $\begin{array}{c}-0.115^{* *} \\
(-2.57)\end{array}$ & & & & \\
\hline $\bar{M}_{1}$ & & $\begin{array}{l}0.125 \\
(1.24)\end{array}$ & & & \\
\hline $\bar{M}_{2}$ & & $\begin{array}{c}0.353^{* * *} \\
(3.79)\end{array}$ & & & \\
\hline $\bar{M}_{3}$ & & $\begin{array}{l}0.216^{*} \\
(1.90)\end{array}$ & & & \\
\hline$\tilde{m}$ & & & $\begin{array}{l}0.129 \\
(1.03)\end{array}$ & & \\
\hline$\tilde{m}^{2}$ & & & $\begin{array}{c}-0.0321 \\
(-1.31)\end{array}$ & & \\
\hline$\tilde{M}_{1}$ & & & & $\begin{array}{l}0.117^{*} \\
(1.89)\end{array}$ & \\
\hline$\tilde{M}_{2}$ & & & & $\begin{array}{c}0.119^{* *} \\
(2.21)\end{array}$ & \\
\hline$\tilde{M}_{3}$ & & & & $\begin{array}{c}0.150^{* *} \\
(2.38)\end{array}$ & \\
\hline$M_{1}$ & & & & & $\begin{array}{c}0.0524^{* *} \\
(2.17)\end{array}$ \\
\hline$M_{2}$ & & & & & $\begin{array}{c}0.110^{* * * *} \\
(5.57)\end{array}$ \\
\hline$M_{3}$ & & & & & $\begin{array}{c}0.0343 \\
(1.63)\end{array}$ \\
\hline _cons & $\begin{array}{c}-0.0232 \\
(-0.08)\end{array}$ & $\begin{array}{c}0.329^{* * *} \\
(3.12)\end{array}$ & $\begin{array}{c}0.405^{* *} \\
(2.23)\end{array}$ & $\begin{array}{c}0.405^{* * *} \\
(4.16)\end{array}$ & $\begin{array}{c}0.469^{* * *} \\
(5.27)\end{array}$ \\
\hline$N$ & 9092 & 9092 & 9092 & 9092 & 9092 \\
\hline$R^{2}$ & 0.265 & 0.265 & 0.264 & 0.265 & 0.267 \\
\hline
\end{tabular}

Dependent variable is a product innovation index. Table shows results from OLS regression. Country and industry fixed effects, age, private ownership, number of employees, and dummies for importer and exporter are omitted from the table. 
Table 6: Product innovation

\begin{tabular}{|c|c|c|}
\hline & $(1)$ & (2) \\
\hline Leader & $\begin{array}{l}-0.463 \\
(-0.63)\end{array}$ & $\begin{array}{c}0.437^{* * *} \\
(3.45)\end{array}$ \\
\hline Leveled & $\begin{array}{c}-1.381^{* *} \\
(-2.11)\end{array}$ & $\begin{array}{l}0.164 \\
(1.47)\end{array}$ \\
\hline $\bar{m}$ & $\begin{array}{c}-0.0988 \\
(-0.22)\end{array}$ & \\
\hline $\bar{m}^{2}$ & $\begin{array}{c}-0.00961 \\
(-0.11)\end{array}$ & \\
\hline Leader $* \bar{m}$ & $\begin{array}{l}0.483 \\
(0.84)\end{array}$ & \\
\hline Leveled $* \bar{m}$ & $\begin{array}{c}0.991^{*} \\
(1.94)\end{array}$ & \\
\hline Leader $* \bar{m}^{2}$ & $\begin{array}{c}-0.0846 \\
(-0.76)\end{array}$ & \\
\hline Leveled $* \bar{m}^{2}$ & $\begin{array}{c}-0.168^{*} \\
(-1.69)\end{array}$ & \\
\hline $\bar{M}_{1}$ & & $\begin{array}{c}0.363^{* *} \\
(2.00)\end{array}$ \\
\hline $\bar{M}_{2}$ & & $\begin{array}{c}0.569^{* * *} \\
(3.19)\end{array}$ \\
\hline $\bar{M}_{3}$ & & $\begin{array}{l}0.311 \\
(1.52)\end{array}$ \\
\hline Leader $* \bar{M}_{1}$ & & $\begin{array}{c}-0.0957 \\
(-0.44)\end{array}$ \\
\hline Leader $* \bar{M}_{2}$ & & $\begin{array}{c}-0.466^{* *} \\
(-2.20)\end{array}$ \\
\hline Leader $* \bar{M}_{3}$ & & $\begin{array}{l}-0.303 \\
(-1.23)\end{array}$ \\
\hline Leveled $* \bar{M}_{1}$ & & $\begin{array}{c}-0.399^{* *} \\
(-2.02)\end{array}$ \\
\hline Leveled $* \bar{M}_{2}$ & & $\begin{array}{l}-0.153 \\
(-0.80)\end{array}$ \\
\hline Leveled $* \bar{M}_{3}$ & & $\begin{array}{c}-0.0343 \\
(-0.16)\end{array}$ \\
\hline _cons & $\begin{array}{l}0.879 \\
(1.53)\end{array}$ & $\begin{array}{l}0.201 \\
(1.47)\end{array}$ \\
\hline $\begin{array}{l}N \\
R^{2}\end{array}$ & $\begin{array}{c}9092 \\
0.266\end{array}$ & $\begin{array}{c}9092 \\
0.267\end{array}$ \\
\hline $\begin{array}{l}t \text { statistics in } \\
* p<0.10, * * \\
\text { Dependent va } \\
\text { results from } 0 \\
\text { age, private o } \\
\text { importer and }\end{array}$ & $\begin{array}{l}\text { arenthese } \\
p<0.05, \\
\text { iable is a } \\
\text { LS regress } \\
\text { vnership, } \\
\text { exporter a }\end{array}$ & $\begin{array}{l}\text { tion index. Table shows } \\
\text { ad industry fixed effects, } \\
\text { loyees, and dummies for } \\
\text { n the table. }\end{array}$ \\
\hline
\end{tabular}


Table 7: Introduction of a new product (probit regression)

\begin{tabular}{|c|c|c|c|c|c|}
\hline & $(1)$ & $\overline{(2)}$ & $\overline{(3)}$ & $\overline{(4)}$ & $\overline{(5)}$ \\
\hline Leader & $\begin{array}{c}0.0936^{* * *} \\
(5.89)\end{array}$ & $\begin{array}{c}0.0934^{* * *} \\
(5.88)\end{array}$ & $\begin{array}{c}0.0944^{* * *} \\
(5.94)\end{array}$ & $\begin{array}{c}0.0947^{* * *} \\
(5.96)\end{array}$ & $\begin{array}{c}0.0902^{* * *} \\
(5.66)\end{array}$ \\
\hline Leveled & $\begin{array}{c}0.00402 \\
(0.29)\end{array}$ & $\begin{array}{c}0.00403 \\
(0.29)\end{array}$ & $\begin{array}{c}0.00470 \\
(0.34)\end{array}$ & $\begin{array}{c}0.00472 \\
(0.34)\end{array}$ & $\begin{array}{c}0.00306 \\
(0.22)\end{array}$ \\
\hline $\bar{m}$ & $\begin{array}{c}0.285^{*} \\
(1.93)\end{array}$ & & & & \\
\hline $\bar{m}^{2}$ & $\begin{array}{c}-0.0623^{* *} \\
(-2.17)\end{array}$ & & & & \\
\hline $\bar{M}_{1}$ & & $\begin{array}{c}0.0755 \\
(1.17)\end{array}$ & & & \\
\hline $\bar{M}_{2}$ & & $\begin{array}{c}0.227^{* * *} \\
(3.78)\end{array}$ & & & \\
\hline $\bar{M}_{3}$ & & $\begin{array}{c}0.192^{* * *} \\
(2.61)\end{array}$ & & & \\
\hline$\tilde{m}$ & & & $\begin{array}{c}0.0594 \\
(0.73)\end{array}$ & & \\
\hline$\tilde{m}^{2}$ & & & $\begin{array}{c}-0.0142 \\
(-0.90)\end{array}$ & & \\
\hline$\tilde{M}_{1}$ & & & & $\begin{array}{c}0.0469 \\
(1.18)\end{array}$ & \\
\hline$\tilde{M}_{2}$ & & & & $\begin{array}{c}0.0584^{*} \\
(1.67)\end{array}$ & \\
\hline$\tilde{M}_{3}$ & & & & $\begin{array}{c}0.0843^{* *} \\
(2.10)\end{array}$ & \\
\hline$M_{1}$ & & & & & $\begin{array}{c}0.0344^{* *} \\
(2.20)\end{array}$ \\
\hline$M_{2}$ & & & & & $\begin{array}{c}0.0691^{* * *} \\
(5.38)\end{array}$ \\
\hline$M_{3}$ & & & & & $\begin{array}{c}0.0195 \\
(1.44)\end{array}$ \\
\hline$N$ & 9092 & 9092 & 9092 & 9092 & 9092 \\
\hline
\end{tabular}

$t$ statistics in parentheses

${ }^{*} p<0.10,{ }^{* *} p<0.05,{ }^{* * *} p<0.01$

Dependent variable is dummy for introduction of new product. Table shows marginal effects at mean values from probit regression. Country and industry fixed effects, age, private ownership, number of employees, and dummies for importer and exporter are omitted from the table. 
Table 8: Introduction of a new product (probit regression)

\begin{tabular}{|c|c|c|}
\hline & (1) & $(2)$ \\
\hline Leader & $\begin{array}{c}-0.390^{* *} \\
(-1.98)\end{array}$ & $\begin{array}{l}0.140^{*} \\
(1.72)\end{array}$ \\
\hline Leveled & $\begin{array}{c}-0.526^{* *} \\
(-2.03)\end{array}$ & $\begin{array}{c}0.00804 \\
(0.11)\end{array}$ \\
\hline $\bar{m}$ & $\begin{array}{l}-0.170 \\
(-0.59)\end{array}$ & \\
\hline $\bar{m}^{2}$ & $\begin{array}{c}0.0168 \\
(0.30)\end{array}$ & \\
\hline Leader $* \bar{m}$ & $\begin{array}{l}0.530 \\
(1.45)\end{array}$ & \\
\hline Leveled $* \bar{m}$ & $\begin{array}{l}0.630^{*} \\
(1.90)\end{array}$ & \\
\hline Leader $* \bar{m}^{2}$ & $\begin{array}{c}-0.0978 \\
(-1.37)\end{array}$ & \\
\hline Leveled $* \bar{m}^{2}$ & $\begin{array}{c}-0.108^{*} \\
(-1.69)\end{array}$ & \\
\hline $\bar{M}_{1}$ & & $\begin{array}{l}0.167 \\
(1.43)\end{array}$ \\
\hline $\bar{M}_{2}$ & & $\begin{array}{c}0.316^{* * *} \\
(2.77)\end{array}$ \\
\hline $\bar{M}_{3}$ & & $\begin{array}{c}0.0931 \\
(0.71)\end{array}$ \\
\hline Leader $* \bar{M}_{1}$ & & $\begin{array}{c}0.0129 \\
(0.09)\end{array}$ \\
\hline Leader $* \bar{M}_{2}$ & & $\begin{array}{l}-0.218 \\
(-1.62)\end{array}$ \\
\hline Leader $* \bar{M}_{3}$ & & $\begin{array}{c}0.0544 \\
(0.35)\end{array}$ \\
\hline Leveled $* \bar{M}_{1}$ & & $\begin{array}{l}-0.183 \\
(-1.44)\end{array}$ \\
\hline Leveled $* \bar{M}_{2}$ & & $\begin{array}{c}-0.0414 \\
(-0.34)\end{array}$ \\
\hline Leveled $* \bar{M}_{3}$ & & $\begin{array}{l}0.147 \\
(1.07)\end{array}$ \\
\hline$N$ & 9092 & 9092 \\
\hline \multicolumn{3}{|c|}{$\begin{array}{l}\text { statistics in parentheses } \\
* p<0.10, * * p<0.05, * * *<0.01 \\
\text { Dependent variable is dummy for introduction of new product. } \\
\text { Table shows marginal effects at mean values from probit regres- } \\
\text { sion. Country and industry fixed effects, age, private ownership, } \\
\text { number of employees, and dummies for importer and exporter } \\
\text { are omitted from the table. }\end{array}$} \\
\hline
\end{tabular}


Table 9: Country income groups with average market power

\begin{tabular}{|c|c|c|c|c|}
\hline & $\begin{array}{l}(1) \\
\text { Low }\end{array}$ & $\begin{array}{c}(2) \\
\text { Lower-middle }\end{array}$ & $\begin{array}{c}(3) \\
\text { Upper-middle }\end{array}$ & $\begin{array}{l}(4) \\
\text { All }\end{array}$ \\
\hline Leader & $\begin{array}{c}0.262^{* * *} \\
(5.48)\end{array}$ & $\begin{array}{c}0.169^{* * *} \\
(5.39)\end{array}$ & $\begin{array}{c}0.313^{* * *} \\
(4.60)\end{array}$ & $\begin{array}{c}0.213^{* * *} \\
(8.66)\end{array}$ \\
\hline Leveled & $\begin{array}{c}0.102^{* *} \\
(2.41)\end{array}$ & $\begin{array}{c}0.00345 \\
(0.12)\end{array}$ & $\begin{array}{c}0.118^{* *} \\
(2.00)\end{array}$ & $\begin{array}{c}0.0462^{* *} \\
(2.13)\end{array}$ \\
\hline $\bar{m}$ & $\begin{array}{l}-0.416 \\
(-0.91)\end{array}$ & $\begin{array}{c}0.915 * * \\
(2.56)\end{array}$ & $\begin{array}{l}0.684 \\
(1.20)\end{array}$ & $\begin{array}{c}0.526^{* *} \\
(2.28)\end{array}$ \\
\hline $\bar{m}^{2}$ & $\begin{array}{c}0.0726 \\
(0.83)\end{array}$ & $\begin{array}{c}-0.191^{* * *} \\
(-2.70)\end{array}$ & $\begin{array}{l}-0.135 \\
(-1.27)\end{array}$ & $\begin{array}{c}-0.115^{* *} \\
(-2.57)\end{array}$ \\
\hline _cons & $\begin{array}{l}0.983 \\
(1.64)\end{array}$ & $\begin{array}{l}-0.530 \\
(-1.18)\end{array}$ & $\begin{array}{c}-0.0888 \\
(-0.11)\end{array}$ & $\begin{array}{c}-0.0232 \\
(-0.08)\end{array}$ \\
\hline$N$ & 2288 & 5122 & 1682 & 9092 \\
\hline$R^{2}$ & 0.206 & 0.319 & 0.207 & 0.265 \\
\hline \multicolumn{5}{|c|}{$\begin{array}{l}t \text { statistics in parentheses } \\
* p<0.10, * * p<0.05, * * *<0.01 \\
\text { Dependent variable is a product innovation index. Table shows } \\
\text { results from OLS regression. Country and industry fixed ef- } \\
\text { fects, age, private ownership, number of employees, and dum- } \\
\text { mies for importer and exporter are omitted from the table. }\end{array}$} \\
\hline
\end{tabular}


Table 10: Country income groups with levels of market power

\begin{tabular}{lcccc}
\hline \hline & $(1)$ & $(2)$ & $(3)$ & $(4)$ \\
& Low & Lower-middle & Upper-middle & All \\
\hline Leader & $0.261^{* * *}$ & $0.169^{* * *}$ & $0.312^{* * *}$ & $0.213^{* * *}$ \\
& $(5.45)$ & $(5.38)$ & $(4.58)$ & $(8.68)$ \\
Leveled & $0.101^{* *}$ & 0.00407 & $0.119^{* *}$ & $0.0469^{* *}$ \\
& $(2.39)$ & $(0.15)$ & $(2.02)$ & $(2.17)$ \\
$\bar{M}_{1}$ & 0.202 & 0.0675 & 0.0616 & 0.125 \\
& $(0.91)$ & $(0.47)$ & $(0.24)$ & $(1.24)$ \\
$\bar{M}_{2}$ & -0.00890 & $0.358^{* * *}$ & 0.275 & $0.353^{* * *}$ \\
& $(-0.05)$ & $(2.59)$ & $(1.22)$ & $(3.79)$ \\
$\bar{M}_{3}$ & 0.103 & 0.130 & 0.367 & $0.216^{*}$ \\
& $(0.38)$ & $(0.79)$ & $(1.46)$ & $(1.90)$ \\
\multirow{2}{*}{ cons } & $0.795^{* * *}$ & $0.325^{* *}$ & -0.0591 & $0.329^{* * *}$ \\
& $(3.65)$ & $(2.51)$ & $(-0.18)$ & $(3.12)$ \\
\hline$N$ & 2288 & 5122 & 1682 & 9092 \\
$R^{2}$ & 0.206 & 0.319 & 0.208 & 0.265 \\
\hline \hline
\end{tabular}

$t$ statistics in parentheses

${ }^{*} p<0.10,{ }^{* *} p<0.05,{ }^{* * *} p<0.01$

Dependent variable is a product innovation index. Table shows results from OLS regression. Country and industry fixed effects, age, private ownership, number of employees, and dummies for importer and exporter are omitted from the table. 
Table 11: Country income groups with average market power

\begin{tabular}{|c|c|c|c|c|}
\hline & $\begin{array}{l}(1) \\
\text { Low }\end{array}$ & $\begin{array}{c}(2) \\
\text { Lower-middle }\end{array}$ & $\begin{array}{c}(3) \\
\text { Upper-middle }\end{array}$ & $\begin{array}{l}(4) \\
\text { All }\end{array}$ \\
\hline Leader & $\begin{array}{l}2.107 \\
(1.57)\end{array}$ & $\begin{array}{l}-1.401 \\
(-1.37)\end{array}$ & $\begin{array}{l}-1.627 \\
(-0.64)\end{array}$ & $\begin{array}{l}-0.463 \\
(-0.63)\end{array}$ \\
\hline Leveled & $\begin{array}{l}0.559 \\
(0.48)\end{array}$ & $\begin{array}{c}-2.400^{* *} \\
(-2.56)\end{array}$ & $\begin{array}{l}-1.459 \\
(-0.62)\end{array}$ & $\begin{array}{c}-1.381^{* *} \\
(-2.11)\end{array}$ \\
\hline $\bar{m}$ & $\begin{array}{l}0.130 \\
(0.18)\end{array}$ & $\begin{array}{l}-0.242 \\
(-0.36)\end{array}$ & $\begin{array}{l}-0.800 \\
(-0.48)\end{array}$ & $\begin{array}{c}-0.0988 \\
(-0.22)\end{array}$ \\
\hline $\bar{m}^{2}$ & $\begin{array}{c}-0.0433 \\
(-0.32)\end{array}$ & $\begin{array}{c}0.0111 \\
(0.08)\end{array}$ & $\begin{array}{l}0.193 \\
(0.63)\end{array}$ & $\begin{array}{c}-0.00961 \\
(-0.11)\end{array}$ \\
\hline Leader $* \bar{m}$ & $\begin{array}{l}-1.530 \\
(-1.48)\end{array}$ & $\begin{array}{l}1.201 \\
(1.45)\end{array}$ & $\begin{array}{l}1.850 \\
(0.97)\end{array}$ & $\begin{array}{l}0.483 \\
(0.84)\end{array}$ \\
\hline Leveled $* \bar{m}$ & $\begin{array}{l}-0.453 \\
(-0.51)\end{array}$ & $\begin{array}{c}1.688^{* *} \\
(2.25)\end{array}$ & $\begin{array}{l}1.590 \\
(0.91)\end{array}$ & $\begin{array}{c}0.991^{*} \\
(1.94)\end{array}$ \\
\hline Leader $* \bar{m}^{2}$ & $\begin{array}{l}0.308 \\
(1.56)\end{array}$ & $\begin{array}{l}-0.226 \\
(-1.37)\end{array}$ & $\begin{array}{l}-0.405 \\
(-1.14)\end{array}$ & $\begin{array}{c}-0.0846 \\
(-0.76)\end{array}$ \\
\hline Leveled $* \bar{m}^{2}$ & $\begin{array}{l}0.103 \\
(0.60)\end{array}$ & $\begin{array}{c}-0.290^{*} \\
(-1.95)\end{array}$ & $\begin{array}{l}-0.359 \\
(-1.12)\end{array}$ & $\begin{array}{c}-0.168^{*} \\
(-1.69)\end{array}$ \\
\hline _cons & $\begin{array}{l}0.371 \\
(0.39)\end{array}$ & $\begin{array}{l}1.091 \\
(1.30)\end{array}$ & $\begin{array}{l}1.450 \\
(0.63)\end{array}$ & $\begin{array}{l}0.879 \\
(1.53)\end{array}$ \\
\hline$N$ & 2288 & 5122 & 1682 & 9092 \\
\hline$R^{2}$ & 0.207 & 0.322 & 0.210 & 0.266 \\
\hline
\end{tabular}

$t$ statistics in parentheses

${ }^{*} p<0.10,{ }^{* *} p<0.05,{ }^{* * *} p<0.01$

Dependent variable is a product innovation index. Table shows results from OLS regression. Country and industry fixed effects, age, private ownership, number of employees, and dummies for importer and exporter are omitted from the table. 
Table 12: Country income groups with levels of market power

\begin{tabular}{|c|c|c|c|c|}
\hline & (1) & $\begin{array}{c}(2) \\
\text { Lower-middle }\end{array}$ & $\begin{array}{c}(3) \\
\text { Unner-middle }\end{array}$ & (4) \\
\hline Leader & $\begin{array}{l}0.222 \\
(1.10)\end{array}$ & $\begin{array}{c}0.924^{* * *} \\
(4.25)\end{array}$ & $\begin{array}{l}-0.183 \\
(-0.59)\end{array}$ & $\begin{array}{c}0.437^{* * *} \\
(3.45)\end{array}$ \\
\hline Leveled & $\begin{array}{l}0.0364 \\
(0.20)\end{array}$ & $\begin{array}{c}0.777 * * * \\
(4.03)\end{array}$ & $\begin{array}{c}-0.603 * * \\
(-2.18)\end{array}$ & $\begin{array}{l}0.164 \\
(1.47)\end{array}$ \\
\hline $\bar{M}_{1}$ & $\begin{array}{l}0.347 \\
(1.04)\end{array}$ & $\begin{array}{c}0.661^{* * *} \\
(2.59)\end{array}$ & $\begin{array}{l}-0.550 \\
(-0.97)\end{array}$ & $\begin{array}{c}0.363^{* *} \\
(2.00)\end{array}$ \\
\hline $\bar{M}_{2}$ & $\begin{array}{c}-0.0206 \\
(-0.07)\end{array}$ & $\begin{array}{c}1.408^{* * * *} \\
(4.96)\end{array}$ & $\begin{array}{l}-0.762 \\
(-1.45)\end{array}$ & $\begin{array}{c}0.569^{* * *} \\
(3.19)\end{array}$ \\
\hline $\bar{M}_{3}$ & $\begin{array}{l}-0.256 \\
(-0.67)\end{array}$ & $\begin{array}{c}0.984^{* * * *} \\
(3.15)\end{array}$ & $\begin{array}{l}-0.596 \\
(-0.93)\end{array}$ & $\begin{array}{l}0.311 \\
(1.52)\end{array}$ \\
\hline Leader $* \bar{M}_{1}$ & $\begin{array}{l}0.246 \\
(0.62)\end{array}$ & $\begin{array}{l}-0.545^{*} \\
(-1.73)\end{array}$ & $\begin{array}{l}0.643 \\
(1.01)\end{array}$ & $\begin{array}{c}-0.0957 \\
(-0.44)\end{array}$ \\
\hline Leader $* \bar{M}_{2}$ & $\begin{array}{c}-0.629 * \\
(-1.76)\end{array}$ & $\begin{array}{c}-1.212^{* * * *} \\
(-3.62)\end{array}$ & $\begin{array}{l}0.988^{*} \\
(1.67)\end{array}$ & $\begin{array}{c}-0.466^{* *} \\
(-2.20)\end{array}$ \\
\hline Leader $* \bar{M}_{3}$ & $\begin{array}{l}0.768^{*} \\
(1.71)\end{array}$ & $\begin{array}{c}-1.174^{* * *} \\
(-3.08)\end{array}$ & $\begin{array}{l}0.635 \\
(0.85)\end{array}$ & $\begin{array}{l}-0.303 \\
(-1.23)\end{array}$ \\
\hline Leveled $* \bar{M}_{1}$ & $\begin{array}{l}-0.522 \\
(-1.40)\end{array}$ & $\begin{array}{c}-0.840 * * * \\
(-2.99)\end{array}$ & $\begin{array}{l}0.762 \\
(1.30)\end{array}$ & $\begin{array}{c}-0.399 * * \\
(-2.02)\end{array}$ \\
\hline Leveled $* \bar{M}_{2}$ & $\begin{array}{l}0.284 \\
(0.90)\end{array}$ & $\begin{array}{c}-1.289^{* * * *} \\
(-4.21)\end{array}$ & $\begin{array}{c}1.261^{* *} \\
(2.33)\end{array}$ & $\begin{array}{l}-0.153 \\
(-0.80)\end{array}$ \\
\hline Leveled $* \bar{M}_{3}$ & $\begin{array}{l}0.247 \\
(0.64)\end{array}$ & $\begin{array}{c}-0.962^{* * * *} \\
(-2.85)\end{array}$ & $\begin{array}{l}1.276^{*} \\
(1.88)\end{array}$ & $\begin{array}{c}-0.0343 \\
(-0.16)\end{array}$ \\
\hline _cons & $\begin{array}{c}0.845^{* * * *} \\
(3.39)\end{array}$ & $\begin{array}{l}-0.326 \\
(-1.62)\end{array}$ & $\begin{array}{l}0.557 \\
(1.37)\end{array}$ & $\begin{array}{l}0.201 \\
(1.47)\end{array}$ \\
\hline $\begin{array}{l}N \\
R^{2}\end{array}$ & $\begin{array}{l}2288 \\
0.213\end{array}$ & $\begin{array}{l}5122 \\
0.323\end{array}$ & $\begin{array}{l}1682 \\
0.212\end{array}$ & $\begin{array}{l}9092 \\
0.267\end{array}$ \\
\hline $\begin{array}{l}t \text { statistics in } \\
* p<0.10, * * \\
\text { Dependent va } \\
\text { sults from OL } \\
\text { private owners } \\
\text { and exporter }\end{array}$ & $\begin{array}{l}\text { arentheses } \\
p<0.05 \text {, }^{*}\end{array}$ & $* * p<0.01$ & 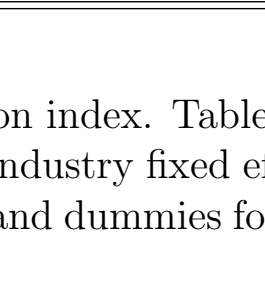 & $\begin{array}{l}\text { lows re- } \\
\text { ts, age, } \\
\text { nporter }\end{array}$ \\
\hline
\end{tabular}

